\title{
Bahasa figuratif dalam puisi-puisi karya Chairil Anwar
}

\author{
Asna Ntelu', Ellyana Hinta², Yelin Yasin3, Supriyadi4 \\ Universitas Negeri Gorontalo $1,2,3,4$ \\ 4Correspondence: supriyadi@ung.ac.id
}

\begin{abstract}
Figurative language in poetry is important to study because figurative language is one part of the physical structure of poetry that can animate or cause certain effect and cause certain connotation of words contained in poetry. This research was carried out to obtain figurative language description in Chairil Anwar's poems. The procedure that was passed from data collection to data interpretation were (a) identifying figurative languages in Chairil Anwar's poems, (b) understanding languages in figurative form, (c) understanding the description of meaning contained in it, and (d) marking the units of segmentation in the form of figurative language. Data analysis was based on three processes, namely the reduction process, the data presentation process, and the verification process. Based on the result of the study obtained, the figurative language is closely related to reality life, poets have a specific purpose in using figurative language, reader must try to understand figurative language in an effort to intact the meaning of a poem, in the poems of Chairil Anwar a number of the beauty of figurative language that can help the reader interpret the meaning of the lines contained there in. Figurative language is presented in his poems to make it easier for reader to interpret the poem. In his poems, Chairil Anwar does not just mention figurative language so that the poems seem interesting, but the inclusion of figurative language was done carefully so that the reader is able to know the meaning of figurative language even though it is considered difficult to interpret.
\end{abstract}

Keywords: figurative language, poetry, reality life, meaning, interpret

\section{Pendahuluan}

Puisi adalah salah satu karya sastra yang berisi ungkapan perasaan seseoramg yang dibubuhi oleh berbagai macam estetika. Salah satu estetika yang terkandung di dalamnya adalah bahasa figuratif atau sering disebut dengan bahasa kias. Menurut Abrams (1981, hlm. 63) bahasa figuratif adalah penyimpangan penggunaan bahasa oleh penutur dari pemahaman bahasa yang dipakai sehari-hari, penyimpangan dari bahasa standar, atau penyimpangan 
makna kata, suatu penyimpangan rangkaian kata supaya diperoleh beberapa arti khusus. Bahasa kias atau figuratif menurut Abrams (1981, hlm. 63-65) terdiri atas simile, metafora, metonimi, sinekdoke, dan personifikasi.

Terdapat banyak puisi dengan keindahan bahasa figuratifnya. Bahasa figuratif dihadirkan dalam puisi untuk membuat pembaca lebih meresapi makna puisi tersebut (Achen, 1978, hlm. 27). Dalam membuat puisi seorang penyair tidak sembarang mencantumkan bahasa figuratif agar puisinya terkesan menarik. Dalam mencantumkan bahasa figuratif seorang penyair harus mampu mengetahui makna yang terkandung dalam kata-kata yang akan dijadikan bahasa figuratif agar pembaca pun bisa memahami meskipun bahasa figuratif yang digunakan oleh penyair termasuk dalam golongan yang sulit untuk diinterpretasi (Russel, 1966, hlm. 53-55). Dengan bahasa figuratif tak sedikit pembaca yang melahirkan banyak interpretasi yang berbeda-beda terhadap suatu puisi tertentu.

Banyak penyair dalam puisinya menggunakan banyak bahasa figuratif. Di antaranya adalah Chairil Anwar. Dalam kumpulan puisi Chairil Anwar tahun 2017jarang ditemukan puisi-puisinya tanpa dihadiri oleh adanya bahasa figuratif yang dapat membantu pembaca menginterpretasi makna dari larik-larik yang terkandung di dalamnya. Sehubungan dengan itu, penelitian terhadap bahasa figuratif adalah penting. Bahasa figuratif merupakan salah satu bagian dari struktur fisik puisi yang dapat menghidupkan atau meningkatkan efek serta menimbulkan konotasi tertentu pada kata-kata yang terdapat dalam puisi (Cirlot, 1962, hlm. 167). Dalam penelitian ini dikaji bahasa figuratif pada kumpulan puisi karya Chairil Anwar tahun 2017. Masalah yang dikaji meliputi hubungan bahasa figuratif dengan kehidupan realitas, tujuan penyair menggunakan bahasa figuratif, kesulitan dalam memaknai bahasa figuratif dalam puisi, dan bahasa figuratif dalam kumpulan puisi Chairil Anwar tahun 2017.

Sebagaimana diketahui bahwa bahasa adalah sebuah sistem lambang bunyi arbitrer yang digunakan oleh masyarakat untuk tujuan komunikasi (Kridalaksana, 1982, hlm. 34). Sebagai sebuah sistem, bahasa bersifat sistematis dan sistemis. Dikatakan sistematis menurut Kridalaksana (1982, hlm. 47) karena bahasa memiliki kaidah atau aturan tertentu. Namun penggunaan bahasa dalam karya sastra sangat berbeda. Menurut Tuloli (1999, hlm. 19) bahasa yang digunakan pada karya sastra lebih banyak mengandung unsur estetika atau unsur keindahan yang banyak dihadirkan oleh para penyair. Dalam karya sastra dikenal dengan esensia poetica, artinya kebebasan penyair. Dalam menghasilkan karya sastra yang indah tentu penyair menggunakan bahasa yang dapat menarik minat baca dari para penikmat sastra, seperti bahasa-bahasa yang hadir dalam bentuk novel, cerpen, puisi, dan drama. Meskipun dalam menciptakan karya sastra diperlukan nilai estetika pada bagian bahasanya perlu diperhatikan juga nilai bahasa itu sendiri. Apakah bahasa yang kita gunakan indah dan baku atau 
hanya bernilai indah tanpa menghiraukan apakah bahasa itu baku atau tidak. Karya sastra yang penulisannya menggunakan bahasa baku akan tetap diminati oleh penikmat sastra. Bila kita ingin menulis sebuah karya sastra, gunakan bahasa Indonesia yang benar karena bahasa yang terdapat dalam karya sastra selain memperkuat keindahan dari karya itu sendiri juga merupakan media penyampaian pesan dari karya sastra tersebut (Chink, Michael, \& Ronald, 1980, hlm. 31). Bahasa yang memperkuat keindahan dalam karya sastra itu tidak lain adalah bahasa figuratif.

Bahasa figuratif atau bahasa kias merupakan penyimpangan dari bahasa yang digunakan sehari-hari, penyimpangan dari bahasa baku atau standar, penyimpangan makna, dan penyimpangan susunan kata-kata supaya memperoleh efek tertentu atau makna khusus (Abrams, 1981, hlm. 63). Bahasa figuratif sebenarnya adalah gaya bahasa kias. Altenbernd \& Lewis. (1966) membedakan bahasa kias dan sarana retoris. Sejalan dengan pendapat Altenbernd \& Lewis, Abrams (1981, hlm. 63) mengelompokkan gaya bahasa kias dan sarana retoris ke dalam bahasa figuratif. Menurutnya, bahasa figuratif sebenarnya merupakan bahasa penyimpangan dari bahasa sehari-hari atau dari bahasa standar untuk memperoleh efek tertentu.

Di sisi lain, bahasa kias merupakan bahasa pembandingan. Istilah bahasa kias atau kiasan ini merupakan terjemahan dari figure of speech. Menurut Kridalaksana (1982, hlm. 85) bahasa kias disebut figure of rhetoric atau rhetorical figure, yaknu alat untuk memperluas makna kata atau kelompok kata untuk memperoleh efek tertentu dengan membandingkan atau mengasosiasiakan dua hal. Menurut Abrams (1981, hlm. 63) bahasa figuratif adalah penyimpangan penggunaan bahasa oleh penutur dari pemahaman bahasa yang dipakai sehari-hari, penyimpangan dari bahasa standar, atau penyimpangan makna kata, suatu penyimpangan rangkaian kata supaya memperoleh beberapa arti khusus. Ditegaskan oleh Wahab (2006, hlm. 73) bahwa bahasa kias merupakan penggantian kata yang satu dengan kata yang lain berdasarkan perbandingan ataupun yang khusus dengan yang khusus.

Berdasarkan sejumlah pendapat ahli di atas dapat dikatakan bahwa bahasa figuratif dapat disebut juga sebagai bahasa kias yang merupakan bahasa perbandingan yang digunakan dalam karya sastra dengan tujuan mempermudah dalam memperoleh beberapa makna dari dua kata atau lebih. Seperti halnya bahasa kias atau bahasa figuratif yang terdapat pada contoh larik puisi karya Chairil Anwar berikut "Aku ini Binatang Jalang”. Pada bentuk bahasa kias aku ini binatang jalang terdapat dua hal yang diperbandingkan, yaitu aku dan binatang jalang. Pada perbandingan tersebut dapat ditemukan adanya kesamaan makna antara aku dan binatang jalang. Kata aku mempunyai makna makhluk hidup atau makhluk bernyawa. Begitu juga dengan kata binatang. 
Pada sisi lain, perbandingan itu juga merujuk pada makna khusus dengan yang lebih khusus. Artinya, kata aku memiliki makna sebagai makhluk hidup yang mempunyai otak dan kesadaran sebagai ciri khususnya, yaitu manusia yang kemudian diperbandingkan dengan binatang yang memiliki makna sebagai makhluk hidup yang memiliki kesadaran tapi tidak memiliki otak dan pikiran. Apalagi dalam puisi tersebut kata binatang diikuti oleh kata jalang yang lebih memperkuat makna dari binatang yang suka hidup di mana-mana termasuk di jalanan. Contoh selanjutnya adalah Kupingku panas mendengar pembicaraannya. Pada pernyataan tersebut kata kupingku meskipun secara tersurat dinyatakan panas tentunya tidak merasakan 'rasa panas' sebagaimana rasa panas akibat terkena api. Kata kupingku pada pernyataan tersebut pada dasarnya merupakan penggantian kata, misalnya perasaan atau hati.

Sementara itu, kata panas menggantikan kata yang lain, misalnya marah atau kesal. Pada interpretasi lain, kata kuping masih dapat dihubungkan dengan alat untuk mendengar. Penggunaan kata panas dapat dihubungkan dengan isi pembicaraan yang tidak menyenangkan. Itulah contoh-contoh pernyataan yang dapat membantu kita mengetahui apa sebenarnya bahasa kias.

Bahasa kias atau figuratif menurut Abrams (1981, hlm. 63-65) terdiri atas (a) simile, (b) metafora, (c) metonimi, (d) sinekdoke, dan (e) personifikasi. Di sisi lain, Pradopo (1994, hlm. 62) membagi bahasa kias ke dalam tujuh jenis, yaitu (a) personifikasi, (b) simile, (c) metafora, (d) alegori, (e) metonimi, (f) sinekdoke, dan (g) perumpamaan.

Berikut adalah ketujuh jenis bahasa figuratif atau bahasa kias menurut Pradopo (1994, hlm. 62), gaya bahasa personifikasi adalah gaya bahasa kias yang menggambarkan benda-benda mati seolah-olah memiliki sifat-sifat kemanusiaan (Pradopo dalam Supriyapto 2011, hlm. 69), gaya simile merupakan gaya pembandingan yang eksplisit, maksudnya adalah gaya yang langung menyatakan sesuatu hal sama dengan hal yang lain (Pradopo dalam Supriyapto, 2011:73). Gaya simile memerlukan kata-kata perbandingan seperti kata bagai, bagaikan, seperti, laksana dan bak. Gaya bahasa simile seperti halnya gaya bahasa personifikasi yang merupakan gaya bahasa perbandingan. Gaya bahasa simile selain digunakan untuk memperoleh nilai estetis juga digunakan sebagai sarana untuk menciptakan suasana cerita menjadi lebih hidup. Hal itu disebabkan oleh adanya efek yang ditimbulkannya, yakni membangkitkan daya khayal. Gaya bahasa metafora adalah gaya bahasa semacam analogi yang membandingkan dua hal secara langsung, tetapi dalam bentuk singkat. Gaya metafora melihat sesuatu dengan perantara benda yang lain (Pradopo dalam Supriyapto, 2011, hlm. 75). Gaya bahasa metafora sebagai perbandingan langsung tidak menggunakan kata-kata seperti, bagaikan, dan lain-lain sehingga pokok pertama langsung dihubungkan dengan pokok kedua. Gaya bahasa alegori adalah cerita kiasan atau pun lukisan kiasan. Gaya bahasa metonimi merupakan 
kata lain dari perpindahan nama. Artinya, suatu kata mendapat arti dari kata lain, misalnya kata kelas pada kalimat Seluruh isi kelas keluar karena bau kentut. punya arti lain. Gaya bahasa sinekdoke atau synecdoche berasal dari kata synekdechesthai yang artinya menerima bersama-sama. Hal itu berarti menggunakan sebagian daripada sesuatu untuk menyatakan keseluruhannya, contoh Tak ada yang berpikir yang saya temui di sana. Yang berpikir yang dimaksud adalah manusia. Gaya bahasa perumpamaan epos/epic simile adalah perbandingan yang dilanjutkan atau diperpanjang dengan cara melanjutkan sifat-sifat perbandingannya dalam kalimat berturut-turut.

\section{Metode}

Jenis penelitian ini adalah deskriptif kualitatif. Dalam hal ini peneliti berusaha mengungkap bahasa figuratif dalam kumpulan puisi-puisi Chairil Anwar tahun 2017. Sumber data adalah puisi-puisi Chairil Anwar tahun 2017. Data penelitian adalah segmen-segmen puisi-puisi Chairil Anwar yang mengandung bahasa figuratif. Sumber data tersebut dimaksudkan untuk mendapatkan korpus bagi masalah dan tujuan penelitian. Instumen utama penelitian ini adalah peneliti sendiri. Teknik pengambilan data adalah teknik dokumen dan observasi langsung pada sumber data (Supriyadi, 2013, hlm. 316), yakni kumpulan puisipuisi karya Chairil Anwar tahun 2017. Selanjutnya, observasi juga dilakukan atas biografi atau kehidupan pribadi penyair sebagai bahan untuk mendeskripsikan data semantik. Prosedur yang dilalui dari pengambilan data sampai dengan pemaknaan data adalah (a) mengidentifikasi bahasa-bahasa figuratif dalam kumpulan puisi-puisi Chairil Anwar, (b) memahami bahasa-bahasa dalam bentuk figuratif, (c) memahami deskripsi makna yang terkandung di dalamnya, dan (d) menandai satuan-satuan segmentasi yang berupa bahasa figuratif. Analisis data didasarkan pada tiga proses, yakni proses reduksi, proses sajian data, dan proses verifikasi (Bogdan \& Biklen, 1982, hlm. 83) dengan berfokus pada bahasa-bahasa figuratif dalam kumpulan puisi-puisi Chairil Anwar tahun 2017.

\section{Hasil dan pembahasan}

\section{Hubungan bahasa figuratif dengan kehidupan realitas}

Telah dijelaskan di depan bahwa bahasa figuratif merupakan penyimpangan dari bahasa yang digunakan sehari-hari, penyimpangan dari bahasa baku atau standar, penyimpangan makna, dan penyimpangan susunan kata-kata supaya memperoleh efek tertentu atau makna khusus. Seorang penyair dalam menciptakan sebuah puisi tentu tidak lepas dari bahasa kias atau bahasa figuratif. 
Selain menambah nilai estetis dalam sebuah puisi, bahasa figuratif ini juga memliki hubungan kehidupan realitas. Seperti halnya bahasa figuratif yang hadir dalam puisi karya Chairil Anwar yang berjudul Hampa berikut.

Hal tersebut sejalan dengan hasil penelitian Supriyadi (2013) yang menyatakan bahwa bahasa figuratif dalam puisi menambah keindahan puisi. Salah satu alasan mengapa puisi kaya akan keindahan adalah bahwa dalam puisi terdapat percampuran antara dunia nyata dan dunia kias, antara makna sesungguhnya dan makna kias. Dalam kaitan itu, Levin (dalam Wahab, 2006, hlm 74) menyatakan bahwa in the poem, there is a mixture of real word and imaginary world reference, or the world of the poem is entirely one of the imagination; but some features, normally of the real world have been transfered into the imaginary world of the poem.

\section{Hampa \\ Kepada Sri}

Sepi di luar. Sepi menekan-mendesak

Lurus kaku pohonan. Tak bergerak

Sampai di puncak. Sepi memagut,

Tak satu kuasa melepas-renggut

Segala menanti. Menanti. Menanti

Sepi

Tambah ini menanti jadi mencekik

Memberat-mencengkung punda

Sampai binasa segala. Belum apa-apa

Udara bertuba. Setan bertempik

Ini sepi terus ada. Dan menanti.

Pada "Hampa" puisi di atas terdapat beberapa bahasa figuratif, yakni (a) lurus kaku pohonan. tak bergerak, (b) tak satu kuasa melepas-renggut, (c) tambah ini menanti jadi mencekik, (d) sampai binasa segala. belum apa-apa, dan (e) udara bertuba. setan bertempik.

Dari sejumlah bahasa figuratif di atas, pembaca sudah bisa mengetahui bahwa sebenarnya penyair sedang mengalami kesepian dan sedang menanti seseorang. Apabila dihubungkan dengan kehidupan realitas atau kehidupan yang nyata bahwa apa yang di alami oleh penyair juga dialami oleh banyak orang. Siapapun yang ada di dunia ini pasti telah mengalami asam manisnya kehidupan. Bahasa figuratif yang diciptakan oleh penyair tentu juga lahir dari masyarakat. Dari berbagai macam bahasa figuratif yang dihasilkan oleh penyair dalam puisi Hampa dapat diketahui bahwa dalam kesepiannya penyair telah menunggu seseorang begitu lama hingga membungkukkan pundaknya sampai tak sanggup lagi menanti. 


\title{
Tujuan penyair menggunakan bahasa figuratif
}

Seorang penyair tidak pernah memiliki batasan dalam menciptakan sebuah puisi. Banyak penyair yang menuangkan isi hatinya dalam karya sastra yang terdiri atas bait dan baris dengan berbagai nilai keindahan. Salah satu aspek yang dapat membuat puisi menjadi lebih indah adalah adanya bahasa kias atau bahasa figuratif. Dari penjelasan tersebut dapat diketahui bahwa tujuan penyair menggunakan bahasa figuratif adaalah untuk menambah nilai estetis pada puisi atau membuat puisi-puisi lebih indah. Tujuan lain penyair menggunakan bahasa kias atau bahasa figuratif adalah menghidupkan atau meningkatkan efek dan menimbulkan konotasi tertentu. Perlu diketahui bahwa bahasa figuratif juga dapat menyebabkan puisi menjadi prismatis. Artinya, memancarkan banyak makna atau kaya akan makna. Penyair lebih banyak menggunakan bahasa kias atau bahasa figuratif dalam puisi tentu memiliki tujuan tertentu terhadap pembaca. Dengan adanya bahasa kias atau bahasa figuratif dalam puisi penyair ingin membuat para pembaca bisa berimajinasi dalam menginterpretasi makna sebenarnya dalam puisi yang telah diciptakannya.

Di sisi lain, keindahan puisi juga disebabkan oleh adanya simbol atau pernyataan simbol. Sebagaimana dinyatakan oleh Russel (1966, hlm. 108) bahwa many poems are based on the symbolic statements. Pernyataan simbolik dalam puisi tersebut sebagai tempat lahirnya metafora yang menambah keindahan sebuah puisi. Simbol-simbol kebahasaan yang digunakan dalam puisi itu merujuk pada pengertian metafora. Simbol metafora yang lahir dalam puisi dapat mengacu pada semantik universal dan semantik yang terikat budaya. Simbol-simbol yang digunakan dalam puisi merupakan kategori metafora nominatif, baik sebagai subjek maupun objek. Simbol sebagai metafora nominatif-subjektif adalah simbol yang digunakan pada puisi yang berkedudukan sebagai subjek, sedangkan simbol sebagai metafora nominatifobjektif adalah simbol yang berfungsi sebagai objek dalam suatu kalimat. Seperti halnya dalam puisi Chairil Anwar yang berjudul Kesabaran berikut.

\section{Kesabaran}

\author{
Aku tak bisa tidur \\ Orang ngomong, anjing nggonggong \\ Dunia jauh mengabur \\ Kelam mendinding batu \\ Dihantam suara bertalu-talu \\ Di sebelahnya api dan abu
}

\author{
Aku hendak bicara \\ Suaraku hilang, tenaga terbang \\ Sudah! Tidak jadi apa-apa! \\ Ini dunia enggan disapa, ambil perduli
}


Keras membeku air kali

Dan hidup bukan hidup lagl

Kuulangi yang dulu kembali

Sambil bertutup telinga, berpicing mata

Menunggu reda yang mesti tiba

Dalam puisi di atas terdapat banyak sekali bahasa figuratif atau bahasa simbol atau bahasa kias yang ditonjolkan oleh penyair. Maksud dan tujuan penyair menggunakan bahasa figuratif dalam puisi di atas adalah penyair ingin memperkuat isi dan makna puisi tersebut. Penyair menginginkan dengan hadirnya bahasa figuratif dalam puisi akan membuat pembaca bisa berfikir lebih keras lagi dalam menginterpretasi atau memaknai puisi yang berjudul Kesabaran di atas.

\section{Kesulitan yang ditemui pembaca dalam memaknai bahasa figuratif}

Dalam memaknai atau mencari maksud bahasa figuratif yang dihadirkan oleh penyair dalam sebuah puisi memang tidak mudah. Banyak pembaca yang kadang salah menginterpretasi bahasa kias atau bahasa figuratif dalam puisi. Kesulitan selanjutnya dalam memaknai puisi adalah berkaitan dengan penggunaan simbol. Pengertian simbol perlu dibedakan antara makna simbol dan makna simbolisme atau metaforis. Menurut Coomaraswamy (dalam Cirlot, 1962) simbolisme merupakan seni berpikir menurut imaji. Sedangkan simbol merupakan ungkapan yang tepat dan terealisasikan yang berhubungan dengan kehidupan inti dan pokok. Dengan kata lain, simbol merupakan lambang umum bukan sebagai mimpi, bukan sebagai bayangan, tapi sebagai suatu kehidupan realistis.

Namun, oleh adanya bahasa kias, penyair mampu menghadirkan banyak makna dalam menginterpretasi sebuah puisi. Meskipun banyak menghasilkan interpretasi yang berbeda-beda, namun pada umumnya para pembaca mampu memaknai tiap puisi meskipun bahasa kias atau bahasa figuratif yang dihadirkan sulit untuk dimaknai. Biasanya kesulitan yang dialami oleh pembaca disebabkan kurangnya ketelitian dalam membaca puisi serta kurangnya pembaca dalam memahami isi puisi tersebut. Hal yang perlu diperhatikan adalah bahwa dalam membaca puisi dibutuhkan sebuah ketelitian agar pembaca bisa mendapatkan makna yang sebenarnya dibalik bahasa kias atau bahasa figuratif yang terdapat dalam puisi.

\section{Bahasa figuratif dalam puisi-puisi karya Chairil Anwar}

Kita perhatikan puisi Chairil Anwar yang berjudul $A k u$ berikut. 


\begin{abstract}
Aku
Kalau sampai waktuku

'Ku mau tak seorang 'kan merayu

Tidak juga kau

Tak perlu sedu sedan itu

Aku ini binatang jalang

Dari kumpulannya terbuang

Biar peluru menembus kulitku

Aku tetap meradang menerjang

Luka dan bisa kubawa berlari

Berlari

Hingga hilang pedih peri
\end{abstract}

Dan akan akan lebih tidak perduli

Aku mau hidup seribu tahun lagi

Puisi yang berjudul $A k u$ karya Chairil Anwar tersebut menceritakan penyair yang begitu bersemangat dalam menghadapi lingkungannya dengan seorang diri. Orang lain tidak harus peduli terhadap apa yang ia lakukan, karena ia juga tidak perduli dengan apa yang mereka lakukan. Dalam mengungkapkan sikap individualitasnya, Chairil Anwar menghadirkan kata-kata yang mengandung bahasa kias atau bahasa figuratif, seperti bahasa figuratif yang terkandung dalam larik puisi $A k u$ ini binatang jalang. Kalimat tersebut mengandung bahasa figuratif atau bahasa kias metafora yang artinya bahasa kias persamaan antara benda yang diganti nama dengan hal yang lain. Dari larik puisi di atas, Chairil Anwar menggambarkan bahwa dirinya seperti binatang jalang. Mengapa Chairil Anwar menggunakan kata binatang jalang? Menurut analisis peneliti, binatang jalang adalah makhluk hidup yang hidup bebas di alam liar, bebas berkeliaran di mana saja tanpa terbebani oleh masalah apapun.

Hal itu menunjukkan bahwa penyair terang-terangan mengungkapkan bahwa dirinya ingin seperti binatang jalang yang hidup bebas. Penyair juga ingin hidup bebas di dunia semesta tanpa ada yang menghalanginya layaknya binatang jalang dengan dunianya. Selain kata binatang jalang yang mengandung majas metafora. Dalam puisi karya Chairil Anwar ini juga terdapat majas hiperbola yang terkandung dalam larik puisi berikut.

Biar peluru menembus kulitku

Aku tetap meradang menerjang

Makna kata tersebut adalah penyair akan tetap berjuang dan tidak akan menyerah dalam melawan kehidupannya dengan seorang diri meskipun 
tantangan dan rintangan yang datang menghadang. Penyair menggunakan kata peluru dalam puisinya. Kata peluru digunakan karena peluru melambangkan tantangan dan rintangan. Peluru adalah sesuatu yang dapat menyakitkan sekaligus mematikan bagi semua orang. Tantangan dan rintangan yang harus dilawan oleh penyair layaknya seperti peluru.

Aku mau hidup seribu tahun lagi

Larik tersebut terkesan terlalu berlebihan. Penyair ingin hidup seribu tahun lagi, sedangkan tak ada manusia yang bisa hidup sampai ribuan tahun kecuali atas kekuasaan Tuhan. Namun, sebenarnya makna yang tersembunyi dibalik kata tersebut adalah seorang penyair yang ingin hidup selama mungkin di dunia. Bahasa figuratif dalam puisi $A k u$ tersebut menurut Supriyanto (2011) merupakan aspek citraan yang penuh dengan intensitas. Artinya, aspek citraan tersebut mampu membangkitkan daya imajinasi saat membaca sebuah puisi. Penyair dituntut cermat dalam memilih kata dan mempertimbangkan maknanya terlebih dahulu agar muncul efek estetik dalam larik puisi yang diproduksi. Gaya penyampaian melalui bahasa figuratif dan citraan ini menjadi penting dalam menentukan tujuan penyair mengungkapkan ekspresinya serta menjadi ciri pembeda dengan karya yang lain.

\author{
Hampa \\ Kepada Sri \\ Sepi di luar. Sepi menekan-mendesak \\ Lurus kaku pohonan. Tak bergerak \\ Sampai di puncak. Sepi memagut, \\ Tak satu kuasa melepas-renggut \\ Segala menanti. Menanti. Menanti \\ Sepi \\ Tambah ini menanti jadi mencekik \\ Memberat-mencengkung pundak \\ Sampai binasa segala. Belum apa-apa \\ Udara bertuba. Setan bertempik \\ Ini sepi terus ada. Dan menanti.
}

Puisi karya Chairil Anwar yang satu itu menceritakan tentang kesepian dan kekosongan hati yang dialami oleh seorang penyair karena penantiannya yang tak berujung. Dalam melukiskan kesepian yang dialaminya, penyair menggunakan bahasa figuratif atau bahasa kias dalam puisinya. Sebagaimana dinyatakan oleh Cirlot (1962, hlm. 167) bahasa figuratif merupakan salah satu bagian dari struktur fisik puisi yang dapat menghidupkan atau meningkatkan efek serta menimbulkan konotasi tertentu pada kata-kata yang terdapat dalam puisi. Bahasa figuratif atau bahasa kias yang terkandung dalam puisi tersebut 
diantaranya majas metafora dan majas hiperbola. Majas metafora hadir pada larik puisi berikut.

Sepi di luar. Sepi menekan-mendesak

Lurus kaku pohonan. Tak bergerak

Sampai di puncak. Sepi memagut,

Tak satu kuasa melepas-renggut

Segala menanti. Menanti. Menanti

Larik-larik puisi di atas menggambarkan suasana hati penyair yang teramat sangat sepi. Mengapa dikatakan teramat sangat sepi?, karena dalam larik tersebut terdapat kata mendesak dan mencekik yang artinya bahwa kesepian yang dirasakan oleh penyair sudah merasuk sampai kedalam jiwanya. Kesepian yang teramat dalam diibaratkan seperti pohon yang tak bergerak. Kita ketahui bersama bahwa pohon adalah tumbuhan yang besar, kuat, dan kokoh. Artinya, kesepian yang dirasakan oleh penyair begitu mendalam sehingga tak ada satu pun yang kuasa untuk menghindari kesepian dan melepas diri dari kesepian yang telah merenggut jiwanya seperti pohon yang telah berakar kuat dan tak mudah untuk roboh. Majas hiperbola terdapat dalam larik puisi berikut.

Tambah ini menanti jadi mencekik

Memberat-mencengkung pundak

Sampai binasa segala. Belum apa-apa

Udara bertuba. Setan bertempik

Ini sepi terus ada. Dan menanti.

Larik-larik puisi di atas memberikan makna bahwa penantian seorang penyair yang mulai merasuk pikirannya. Penantian tersebut semakin lama semakin mencekik kehidupannya. Penantian yang penyair alami membuatnya semakin terbebani. Beban tersebut semakin lama semakin berat, sehingga penyair tak mampu menahannya. Penyair merasa bebannya begitu berat hingga terasa sampai di pundaknya, semakin beban itu terasa lebih berat, pundaknya tak mampu menahan beratnya hingga akhirnya pundaknya mencekung karena tidak terlalu kuat untuk menahan berat bebannya. Pada umumnya bahasa kias atau bahasa figuratif yang hadir pada larik puisi di atas lebih menggambarkan bahwa ketidakmampuan seorang penyair dalam menahan bebannya yang selama ini menanti seorang kekasih.

Selain majas metafora dan hiperbola. Dalam puisi Hampa juga terdapat majas repitisi, yaitu pengulangan kata pada larik puisi. Seperti pengulangan kata pada kata Sepi dan Menanti. Pengulangan pada dua kata tersebut untuk menggambarkan dan memberitahukan kepada pembaca bahwa penyair benarbenar mengalami kesepian yang mendalam karena penantiannya tidak pernah berujung. Wanita yang dinantinya tidak pernah datang menjumpai dirinya.

\section{Kesabaran}

Aku tak bisa tidur

Orang ngomong, anjing nggonggong 
Dunia jauh mengabur

Kelam mendinding batu

Dihantam suara bertalu-talu

Di sebelahnya api dan abu

Aku hendak bicara

Suaraku hilang, tenaga terbang

Sudah! Tidak jadi apa-apa!

Ini dunia enggan disapa, ambil perduli

Keras membeku air kali

Dan hidup bukan hidup lagl

Kuulangi yang dulu kembali

Sambil bertutup telinga, berpicing mata

Menunggu reda yang mesti tiba

Pada puisi Kesabaran karya Chairi Anwar itu bercerita tentang kehidupan penyair yang menghadapi masalah dengan lingkungannya. Masalah yang dihadapi berupa peperangan yang tidak henti-hentinya. Namun, penyair hanya bisa berharap dan berusaha memperbaiki semuanya dengan tidak memperdulikan dengan apa yang telah terjadi, hingga semuanya akan benarbenar berakhir. Dalam melukiskan peperangan yang terjadi dalam puisi itu, penyair menghadirkan beberapa bahasa figuratif atau bahasa kias atau majas. Namun pada puisinya kali ini, Chairil Anwar lebih dominan menggunakan majas personifikasi yang terdapat pada larik-larik puisi berikut.

\author{
Aku tak bisa tidur \\ Orang ngomong, anjing nggonggong \\ Dunia jauh mengabur \\ Kelam mendinding batu \\ Dihantam suara bertalu-talu \\ Di sebelahnya api dan abu \\ Aku hendak bicara \\ Suaraku hilang, tenaga terbang \\ Sudah! Tidak jadi apa-apa! \\ Ini dunia enggan disapa, ambil perduli
}

Pada larik tersebut terlihat ketakutan dari si Aku. Ia tidak bisa tidur karena adanya suara-suara yang mencekam dari orang-orang di sekililingnya yang disertai dengan suara besar yang bertalu-talu yang berasal dari alat-alat peperangan, sehingga mengakibatkan adanya suara ledakan, api, dan abu yang berterbangan. Semua itu menyebabkan lingkungan disekitarnya mengabur, kelam, dan tidak dapat dipandang dengan jelas. Kata Dunia jauh mengabur mengandung majas personifikasi. Mengabur pada umumnya adalah kejadian atau masalah yang sering dialami oleh mata. Dunia tidak memiliki mata. Yang di maksud dengan dunia pada larik tersebut adalah lingkungan sekitar penyair. 
Begitu juga dengan larik Dihantam suara bertalu-talu. Kata hantam merupakan kegiatan yang dilakukan oleh manusia. Biasanya kata hantam berhubungan dengan benda-benda keras, sedangkan pada larik puisi di atas kata hantam dilekatkan dengan suara yang diikuti dengan kata bertalu-talu. Jadi, maksud larik puisi tersebut adalah suara-suara ledakan yang keras yang berbunyi berulang-ulang.

Pada larik Suara hilang tenaga terbang juga mengandung majas personifikasi. Kata terbang hanya dimiliki oleh makhluk hidup yang memiliki sayap yang bisa terbang. Kata terbang yang melekat pada kata tenaga dapat memberi makna bahwa penyair telah kehilangan tenaganya. Ia menjadi tak berdaya, sedangkan kata enggan yang melekat pada kata dunia memberikan makna bahwa dunia atau lingkungannya sudah tak seperti dulu lagi, semuanya sibuk dengan masalah yang terjadi tanpa perduli dengan lingkungan sekitarnya. Kata enggan dapat diibaratkan seperti kata malu. Kata malu hanya dimiliki oleh manusia sedangkan dunia bukan merupakan manusia.

\author{
Sajak putih \\ Bersandar pada tari warna pelangi \\ Kau depanku bertudung sutra senja \\ Di hitam matamu kembang mawar dan melati \\ Harum rambutmu mengalun bergelut senda \\ Sepi menyanyi, malam dalam mendoa tiba \\ Meriak muka air kolam jiwa \\ Dan dalam dadaku memerdu lagu \\ Menarik menari seluruh aku \\ Hidup dari hidupku, pintu terbuka \\ Selama matamu bagiku menengadah \\ Selama kau darah mengalir dari luka \\ Antara kita Mati datang tidak membelah... \\ 1944
}

Kata sajak dalam puisi karya Chairil Anwar itu merupakan kiasan isi hati dari sang penyair. Kata putih mengiaskan kejujuran dan ketulusan serta keikhlasan dari si Aku yang merupakan penyair itu sendiri. Jika digabungkan menjadi kata Sajak Putih akan mengandung makna Suara hati si Aku atau penyair yang sangat tulus dan jujur. Puisi di atas menceritakan isi hati sang penyair kepada seorang wanita yang begitu tulus dan ikhlas.

Pada puisi karya Chairil Anwar tersebut juga banyak hadir bahasa figuratif, seperti yang terdapat pada baris ketiga dihitam matamu kembang mawar dan melati, merupakan bahasa figuratif. Mawar dan melati yang mekar menggambarkan sesuatu yang indah dan menarik. Warna merah menggambarkan cinta, sedangkan yang warna putih menggambarkan kesucian. Dalam mata si gadis tampak cinta yang tulus, menarik, dan memikat. Selain itu, muncul pula bahasa figuratif. Repetisi pada baris kesembilan, yaitu terjadi pengulangan kata, Hidup dari hidupku yang menggambarkan bahwa penyair 
ingin menjadikan gadis tersebut bagian dari hidupnya. Bahasa figuratif lain yang hadir dalam puisi diatas diantaranya Tari warna pelangi, Rambutmu mengalun bergelut senda yang merupakan bahasa kias personifikasi yang menggambarkan benda mati seolah-olah hidup. Berikut bahasa figuratif yang terdapat dalam puisi Doa.

\section{Doa}

kepada pemeluk teguh

Tuhanku

Dalam termangu

Aku masih menyebut namaMu

Biar susah sungguh

mengingat Kau penuh seluruh

cayaMu panas suci

tinggal kerdip lilin di kelam sunyi

Tuhanku

aku hilang bentuk

remuk

Tuhanku

aku mengembara di negeri asing

Tuhanku

di pintuMu aku mengetuk

aku tidak bisa berpaling

Puisi di atas menggambarkan sebuah renungan diri penyair yang menyadari bahwa dirinya tidak bisa lepas dari Tuhannya. Bahasa fuguratif yang terdapat dalam puisi Doa di antaranya hiperbola yang terdapat pada larik berikut.

Biar susah sungguh

mengingat Kau penuh seluruh

Larik di atas terkesan berlebihan. Hal tersebut dilukiskan oleh penyair untuk menggambarkan bahwa meskipun dalam keadaan susah apapun, penyair tetap berusaha mengingat Tuhannya.

Tuhanku

aku hilang bentuk

remuk 
Pada larik di atas juga terkesan berlebihan. Penyair menggambarkan bahwa dirinya hilang bentuk dan remuk. Maksud pernyataan tersebut adalah si penyair telah kehilangan arah, ia menghadapi masalah yang begitu sulit namun hanya kepada Tuhanlah ia bisa menceritakan semuanya.

\section{Kesimpulan}

Penelitian terhadap bahasa figuratif dalam puisi penting dilaksanakan karena bahasa figuratif merupakan salah satu bagian dari struktur fisik puisi yang dapat menghidupkan atau meningkatkan efek serta menimbulkan konotasi tertentu pada kata-kata yang terdapat dalam puisi. Dalam kumpulan puisi Chairil Anwar jarang ditemukan puisinya yang tanpa dihadiri oleh adanya bahasa figuratif yang hal itu dapat membantu pembaca dalam menginterpretasi makna dari larik-laris yang terkandung di dalam puisinya. Banyak puisi dengan keindahan bahasa figuratifnya mampu menggugah estetika dan rasa emosional pembacanya. Bahasa figuratif dihadirkan dalam puisi untuk membuat pembaca lebih mudah dalam memaknai arti puisi tersebut. Dalam menggubah puisi seorang penyair mesti berhati-hati dan tidak sembarang mencantumkan bahasa figuratif agar puisinya menarik dan memiliki nilai-nilai etika serta estetika. Dalam mencantumkan bahasa figuratif penyair harus mampu mengetahui makna yang terkandung dalam kata-kata yang dijadikan sebagai bahasa figuratif agar pembaca pun bisa memahami meskipun bahasa figuratif yang dicantumkan oleh penyair tergolong sulit untuk diinterpretasi. Dalam memahami dan memaknai bahasa figuratif yang dihadirkan oleh penyair dalam sebuah puisi memang sulit. Banyak pembaca yang kadang salah dalam menginterpretasi bahasa kias atau bahasa figuratif dalam puisi.

\section{Daftar rujukan}

Abrams. (1981). Teori pengantar fiksi. Yogyakarta: Hanindita Graha Wida.

Achen, S.T. (1978). Symbols around us. New York: Van Nostrand Reinhold Company.

Altenbernd, L. \& Leslie L.Lewis. (1966). A handbookfor the study of fiction. New York: The Macmillan.

Bogdan, R.C. \& Sari Kropp Biklen. (1982). Qualitative research for education: An introduction to theory and methods. Boston: Allyn and Bacon Inc.

Chink, M.K.L, Michael C.H., \& Ronald F.L. (eds). (1980). Linguistic perspective on literature. London: Routledge \& Kegan Paul Ltd.

Cirlot, J.E. (1962). A dictionary of symbols. Second edition. New York: Philosophical Library Inc.

Kridalaksana, H. (1982). Kamus linguistik. Jakarta: Gramedia. 
Kumpulan puisi Chairil Anwar tahun 2017, (Online), (https://deweezz.com/kumpulan-puisi-chairil-anwar/), diakses 25 Januari 2020.

Pradopo, R.J. (1994). Prinsip-prinsip kritik sastra: Teori dan penerapannya. Gadjah Mada University Press.

Russel, C.R. (1966). How to analyze poetry. New York: Monarch Press.

Supriyadi (2013) Ungkapan-ungkapan metaforis dalam puisi-puisi karya Agus R. Sarjono. Litera: Jurnal Penelitian Bahasa, Sastra, dan Pengajarannya. Volume 12, Nomor 2, Oktober 2013, (312-327).

Supriyanto, T. (2011). Kajian Stilistika dalam Prosa.

Yogyakarta: Elmatera.

Supriyapto. (2011). Psikologi populer. Jakarta: Gramedia Widiasarana.

Tuloli, N. (1999). Penyair dan sajaknya. Gorontalo: Percetakan STKIP Gorontalo.

Wahab, A. (2006). Butir-butir linguistik. Surabaya: Airlangga University Press 